\title{
Sesbania exaltata biocontrol with Colletotrichum truncatum microsclerotia formulated in 'Pesta' granules
}

\author{
C. Douglas BOYETTE ${ }^{1, *}$, Mark A. JACKSON ${ }^{2}$, \\ Charles T. BRYSON ${ }^{1}$, Robert E. HOAGLAND ${ }^{1}$, \\ William J. CONNICK Jr. ${ }^{3}$ and Donald J. DAIGLE ${ }^{3}$ \\ ${ }^{1}$ Southern Weed Science Research Unit, United States Department of Agriculture, \\ Agricultural Research Service, Stoneville, 38776, MS, USA; ${ }^{2}$ National Center for \\ Agricultural Utilization Research, United States Department of Agriculture, \\ Agricultural Research Service, Peoria, 30801, IL, USA; ${ }^{3}$ Southern Regional \\ Research Center, United States Department of Agriculture, Agricultural \\ Research Service, New Orleans, LA, 71709, USA \\ *Author for correspondence (e-mail:dboyette@ars.usda.gov)
}

Received 18 January 2005; accepted in revised form 14 June 2006

\begin{abstract}
The weed Sesbania exaltata (Raf.) Rydb. ex A.W. Hill (hemp sesbania) was effectively controlled in soybean [Glycine $\max$ (L.) Merr.] field test plots over a 2-year testing period (1995-1996) with microsclerotia of the bioherbicidal fungus, Colletotrichum truncatum, formulated in wheat gluten-kaolin granules called 'Pesta'. Weed control averaged $84 \%$ and $88 \%$, respectively, in plots treated pre-plant incorporated (PPI) at 'Pesta' rates of 168 or $336 \mathrm{~kg} \mathrm{ha}^{-1}$, and $71 \%$ and $78 \%$, respectively, in plots treated pre-emergence (PE) at 'Pesta' rates of 168 or $336 \mathrm{~kg} \mathrm{ha}^{-1}$ over the testing period. Post-emergence (POE) control averaged $30 \%$ and $50 \%$, respectively, for the 168 and $336 \mathrm{~kg} \mathrm{ha}^{-1}$ treatments, and was significantly less effective than either PE or PPI treatments. Although pathogenesis and mortality occurred in hemp sesbania tissues, satisfactory weed control was not achieved in plots treated at rates of 17 or $84 \mathrm{~kg} \mathrm{ha}^{-1}$ with any of the application methods. Soybean yields were significantly greater in test plots treated PPI or PE, as compared to yields from test plots treated either POE, with inert 'Pesta' granules, or from untreated controls. Microsclerotia formulated in 'Pesta' granules exhibited excellent shelf-life, retaining high viability after storage for 10 years at $4{ }^{\circ} \mathrm{C}$. These results suggest that microsclerotia of $C$. truncatum formulated in 'Pesta' granules offers an effective method for controlling this important weed and preserving the activity of this bioherbicide.
\end{abstract}

Key words: biological weed control, bioherbicide, Colletotrichum truncatum, Fabaceae, formulation, hemp sesbania, phytopathogen, soybean 


\section{Introduction}

Sesbania exaltata (Raf.) Rydb. ex A.W. Hill (hemp sesbania), is a vigorous, nodulating leguminous weed in soybean [Glycine max (L.) Merr.], cotton (Gossypium hirsutum L.) and rice (Oryza sativa L.), capable of reaching heights of $3 \mathrm{~m}$ at maturity (Lorenzi and Jeffery, 1987). Hemp sesbania ranks as one of the 10 most troublesome weeds in the three southern U.S. states of Arkansas, Louisiana, and Mississippi (Dowler, 1997), reducing crop seed yield by shading and competition (King and Purcell, 1997). Hemp sesbania is a prolific seed producer, yielding up to 21,000 seed plant $^{-1}$ (Lovelace and Oliver, 2000). Populations of $0.8-12.9$ hemp sesbania plants $\mathrm{m}^{-2}$ emerging with soybean reduced the yield of wide-row $(1 \mathrm{~m})$ soybean $10-80 \%$ when allowed to interfere throughout the growing season (McWhorter and Anderson, 1979). Emergence is characterized as quasi-simultaneous, therefore, if a dense crop canopy is not formed soon after application of a postemergence herbicide that lacks residual control, weed re-infestation will likely result (Lovelace and Oliver, 2000).

Previous research has shown that conidial formulations of the fungus Colletotrichum truncatum (Schw.) Andrus \& Moore are effective in controlling hemp sesbania under field conditions. (Boyette et al., 1993b). In addition to producing mycelium (hyphae) and conidia in solid and liquid culture, C. truncatum can also be induced to produce structures called microsclerotia, which are compact, dense aggregates of darkly pigmented, thick-walled hyphal cells that can remain dormant for long periods until conditions favorable for growth to occur (Agrios, 1988). C. truncatum microsclerotia can be produced in submerged liquid culture and stored in diatomaceous earth (Jackson and Schisler, 1994). Pre-emergence soil application of the dry microsclerotia/ diatomaceous earth formulation infected and killed hemp sesbania seedlings in growth chamber studies. Dried microsclerotia formulated with pre-gelatinized corn flour and pre-gelatinized cornstarch prompted disease development in emerging hemp sesbania seedlings (Jackson et al., 1996). When conditions are favorable $\left(20-30{ }^{\circ} \mathrm{C}\right.$, moist soil), $C$. truncatum microsclerotia "germinate" and form actively growing mycelia and conidia that infect stems and root surface cells of hemp sesbania, or directly invade roots through wounds (Schisler and Jackson, 1996).

To effectively apply the fungus in the field, a formulation that is biologically effective and also stable in storage is needed. Excellent shelf-life resulted when $C$. truncatum microsclerotia were encapsulated 
in granules made with wheat flour and kaolin clay ('Pesta') (Connick et al., 1997). Shelf-life was at least one year at $25{ }^{\circ} \mathrm{C}$ when a minimum of 7 microsclerotia granules ${ }^{-1}$ were encapsulated. The objective of this study was to determine if microsclerotia of $C$. truncatum formulated with 'Pesta' could effectively control the problematic weed hemp sesbania in soybean under field conditions.

\section{Materials and methods}

\section{Chemicals}

All chemicals used in media were of reagent grade or higher in purity and were products of Sigma Chemical Corp., St Louis, MO, USA. Agar, potato dextrose agar (PDA), and vitamin-free casamino acids were purchased from Difco, Detroit, MI, USA. ${ }^{1}$ The herbicides trifluralin $\left(\alpha, \alpha, \alpha\right.$-trifluoro-2,6-dinitro- $N, N$-dipropyl-p-toluidine) (Treflan ${ }^{\circledR}$ ) and acifluorfen [5-(2-chloro- $\alpha, \alpha, \alpha$-trifluoro- $p$-tolyloxy)-2-nitrobenzoic acid] (Blazer ${ }^{\circledR}$ ) were commercially formulated products of Dow AgroSciences $^{\mathrm{TM}}$ (Indianapolis, IN, USA) and BASF (Research Triangle Park, NC, USA), respectively, and were purchased from a local supplier.

\section{Fungal culture and growth condition}

The isolate of $C$. truncatum used in this study was originally isolated from hemp sesbania seedlings and is deposited at the National Center for Agricultural Research Utilization, Peoria, IL, USA (NRRL Deposit No. 18434). Stock cultures of C. truncatum were maintained either on PDA slant tubes or in twice-autoclaved fine sandy loam soil adjusted to $25 \%$ water-holding capacity (Tuite, 1969). Liquid cultures were produced from the fungus grown on PDA plates as previously described (Jackson and Bothast, 1990).

\section{Media and culture condition}

The medium used for $C$. truncatum microsclerotia production contained $1^{-1}$ : glucose, $80 \mathrm{~g}$; vitamin-free casamino acids, $13.2 \mathrm{~g}$; $\mathrm{KH}_{2} \mathrm{PO}_{4}, 2.0 \mathrm{~g} ; \mathrm{CaCl}_{2} \cdot 2 \mathrm{H}_{2} \mathrm{O}, 0.4 \mathrm{~g} ; \mathrm{MgSO}_{4} \cdot 7 \mathrm{H}_{2} \mathrm{O}, 0.3 \mathrm{~g} ; \mathrm{CoCl}_{2} \cdot 6-$ $\mathrm{H}_{2} \mathrm{O}, 37 \mathrm{mg} ; \mathrm{FeSO}_{4} \cdot 7 \mathrm{H}_{2} \mathrm{O}, 50 \mathrm{mg} ; \mathrm{MnSO}_{4} \cdot \mathrm{H}_{2} \mathrm{O}, 16 \mathrm{mg} ; \mathrm{ZnSO}_{4} \cdot 7-$ $\mathrm{H}_{2} \mathrm{O}, 14 \mathrm{mg}$; thiamin, riboflavin, pantothenate, niacin, pyridoxamine, thiotic acid, $500 \mathrm{mg}$ each; folic acid, biotin, vitamin $\mathrm{B}_{12}, 50 \mathrm{mg}$ each. 
The medium had an initial $\mathrm{pH}$ of 5.5, and $\mathrm{pH}$ was not controlled during culture growth.

\section{Production of C. truncatum microsclerotia}

Colletotrichum truncatum conidial inoculum for all submerged cultures provided a final concentration of $5 \times 10^{4}$ spores $\mathrm{ml}^{-1}$. Microsclerotia of $C$. truncatum were produced in a 30-1 fermenter (B. Braun, Model C-30, Bethlehem, PA, USA) at a 20-1 working volume using the medium previously described (Jackson et al., 1996). The fermentation was carried out at $28{ }^{\circ} \mathrm{C}$, with an aeration rate of 101 air $\mathrm{min}^{-1}$, and agitation was set at $250 \mathrm{rpm}$ using 2 Rushton style impellers. A siliconbased antifoam (HODAG FD-62, Lambent Technologies, Gurnee, IL, USA) was used to control foaming, as required.

\section{Microsclerotia harvesting, drying, and storing}

Microsclerotia were separated from 11-day-old C. truncatum shake flask cultures and 18-day-old fermenter cultures by sieving the culture broth, through a 40-mesh $(425: \mathrm{m})$ screen, and then through an 80 mesh $(180: \mathrm{m})$ screen. Microsclerotia that collected on the 80 -mesh screen (180-425:m in size) were used for all drying, storage, and efficacy studies. Sieved microsclerotia were rinsed and collected in deionized water. Excess deionized water was removed from settled microsclerotia, and 5\% diatomaceous earth $\left(\right.$ HYFLO $^{\circledR}$, Celite, Corp., Lompoc, CA, USA) (w/v) was added to the microsclerotia suspension. The microsclerotia-diatomaceous earth mixture was vacuum-filtered in a Buchner funnel using Whatman No. 1 filter paper. The filter cake was broken up, placed in shallow glass trays, and air-dried overnight at $22{ }^{\circ} \mathrm{C}$ in an operating biological safety cabinet. The moisture content of dried microsclerotial preparations was determined with a moisture analyzer (Mark I, Denver Instruments, Arvada, CO, USA). Dried microsclerotia formulations $(<5 \%$ moisture) were placed in zip-lock bags and stored at $4{ }^{\circ} \mathrm{C}$.

\section{Preparation of 'Pesta' granules}

'Pesta': C. truncatum microsclerotia granules were prepared by modifying methods described previously (Connick et al., 1991; Boyette et al., 1993b). Briefly, the dried microsclerotia formulation was suspended in $23 \mathrm{ml}$ sterilized distilled water and added to an 80:20 (w:w) mixture of semolina (durum) wheat flour, and kaolin. The mixture 
was kneaded to make a dough, pressed flat, folded by hand five times, and extruded through a table-mounted pasta maker. The sheets (ca. $15-25 \mathrm{~cm}$ wide; $1.0-1.5 \mathrm{~mm}$ thick) were air-dried on elevated polyester screens for 3 days at $22{ }^{\circ} \mathrm{C}$ and $50-60 \%$ relative humidity. The dried sheets were broken, milled, and sieved to obtain 14 to 18 mesh $(1-1.4 \mathrm{~mm})$ granules, and stored at $4{ }^{\circ} \mathrm{C}$. The final dried product contained ca. 7 microsclerotia granule ${ }^{-1}$. Previous work has shown that a 'Pesta': C. truncatum microsclerotia granule such as this would produce from 1.3 to $4.5 \times 10^{8}$ conidia (Connick et al., 1997).

\section{Viability of 'Pesta': C. truncatum microsclerotia granules}

One hundred granules (about $0.1 \mathrm{~g}$ ) were randomly sampled from pooled inoculum that had been produced for greenhouse and field testing. The granules were placed on moistened filter paper contained in petri plates and were incubated for $24 \mathrm{~h}$ at $25^{\circ} \mathrm{C}$ with a light regime of $12 \mathrm{~h} / 12 \mathrm{~h}$ (dark/light). Following incubation, the granules were visually examined for evidence of fungal growth.

\section{Greenhouse bioassay of granules}

Hemp sesbania seeds were mechanically scarified using a rotary, sandpaper scarifier (Forsberg Co., Thief River Falls, MN, USA) and then planted in a commercial potting mixture supplemented with a controlled-release $(14: 14: 14, \mathrm{~N}: \mathrm{P}: \mathrm{K})$ fertilizer contained in peat strips (12, $5.5 \mathrm{~cm}^{-2}$ pots strip ${ }^{-1}$ ). Seeding rates were 3 seeds $\operatorname{pot}^{-1}$, for a total of 36 seeds strip ${ }^{-1}$. 'Pesta': $C$. truncatum microsclerotia granules were applied either pre-plant incorporated (PPI), pre-emergence (PE) or post-emergence (POE) at rates of $1.0 \mathrm{~g}$ of granules pot $^{-1}$. Post-emergence applications were made when hemp sesbania seedlings were in the cotyledonaryto-first leaf growth stage. Control pots were treated with 'Pesta' granules containing no fungus. Following inoculation, the plants were incubated on sub-irrigated greenhouse trays and monitored for 14 days for disease development and mortality. Greenhouse temperatures were $28-32{ }^{\circ} \mathrm{C}$, with $60-90 \%$ relative humidity and day lengths were $12 \mathrm{~h}$ with an average of $1850 \mu \mathrm{mol} \mathrm{m}^{-2} \mathrm{~s}^{-1}$ photosynthetically active radiation at mid-day. Surviving plants were excised at the soil line, oven dried for $48 \mathrm{~h}$ at $85^{\circ} \mathrm{C}$, weighed, and percentages of biomass reductions were determined.

Treatments were replicated three times with 36 individual seedlings in each replication. The test was repeated twice, and data were averaged, followed by subjection to Bartlett's test for homogeneity of 
variance (Gomez and Gomez, 1984). A randomized complete block experimental design was used. Data were subjected to analysis of variance. Nontransformed data for weed control are presented because arcsine square-root transformation did not alter interpretation of data. Significant differences in were determined using Fisher's Protected Least Significant Difference (FLSD) at $p=0.05$.

\section{Field experiments}

Field experiments were conducted on a Dundee very fine sandy loam (Aeric Ochraqualf) soil in June 1995 and 1996 at the USDA-ARS, Southern Weed Science Experimental Farm, Stoneville, MS. Trifluralin [2,6-dinitro- $N, N$-dipropyl(trifluoromethyl)benzenamine] was applied PPI to the test area at a broadcast rate of $1.12 \mathrm{~kg} \mathrm{ha}^{-1}$ to control grass weeds. Plots consisted of four rows of soybeans (cv. 'Centennial'), $12.2 \mathrm{~m}$ long and $1 \mathrm{~m}$ apart, with only the two center rows receiving treatment. All rows were planted with scarified hemp sesbania seed at a density of about 100 seeds $\mathrm{m}^{-1}$ of row. Treatments consisted of: 'Pesta': C. truncatum microsclerotia granules applied PPI, PE, or POE at 17, 84, 168 , or $336 \mathrm{~kg} \mathrm{ha}^{-1}$, a herbicide control (acifluorfen, \{5-[2-chloro-4trifluoromethyl)phenoxy]-2-nitrobenzoic acid\}) applied POE at $1.1 \mathrm{~kg} \mathrm{ha}^{-1}$, and an untreated control. In plots receiving PPI and PE applications, treatments were made on planting dates of June 6, 1995 and June 13, 1996, respectively. 'Pesta' granules were dispensed using a tractor-mounted fertilizer spreader. POE applications were made manually when hemp sesbania seedlings were in the cotyledonary-to-first leaf growth stage. All 'Pesta' applications were applied in 46-cm bands in the treated center two rows of each plot. Percentage data of hemp sesbania controlled and biomass reductions were determined in randomly selected 6,1-m subplots from each treated plot 4 weeks after treatment. The experimental plots were furrow-irrigated about 4 weeks after treatment and as required to maintain healthy hemp sesbania and soybean plants throughout the growing season.

The experiments were arranged as randomized complete block designs with four replications. Data over the 2 years were averaged, followed by subjection to Bartlett's test for homogeneity of variance (Gomez and Gomez, 1984). Data were analyzed using analysis of variance. As in greenhouse experiments, nontransformed data for weed control are presented because arcsine square-root transformation did not alter interpretation of data. Weed control and soybean yield data were subjected to regression analysis. 


\section{Results and discussion}

\section{Viability of granules}

C. truncatum microsclerotia, encapsulated in 'Pesta' granules, began to germinate and were discernible about $8-10 \mathrm{~h}$ after granules were placed on moistened filter paper and incubated at $25^{\circ} \mathrm{C}$. Fungal growth (conidia and mycelia) was visually evident after $24 \mathrm{~h}$ (Figure 1) and propagule viability in these granule tests exceeded 95\% (data not shown). In our present study we found that C. truncatum microsclerotia formulated in 'Pesta': granules were still viable, and possessed high viability even after 10 years storage at $4{ }^{\circ} \mathrm{C}$ (Figure 2).

Previous research with conidia of $C$. truncatum formulated in 'Pesta' granules, showed that conidia were produced for at least 10 days, yielding a cumulative total of $10^{8}$ conidia $\mathrm{g}^{-1}$ of 'Pesta' (Connick et al., 1991). A more definitive study detailing C. truncatum conidia shelf-life encapsulated in 'Pesta' granules was also reported (Connick et al., 1996). In another study using microsclerotia of $C$. truncatum formulated in 'Pesta', shelf-life was at least one year when a minimum of 7 microsclerotia granule ${ }^{-1}$ were encapsulated and stored at $25^{\circ} \mathrm{C}$ (Connick et al., 1997).

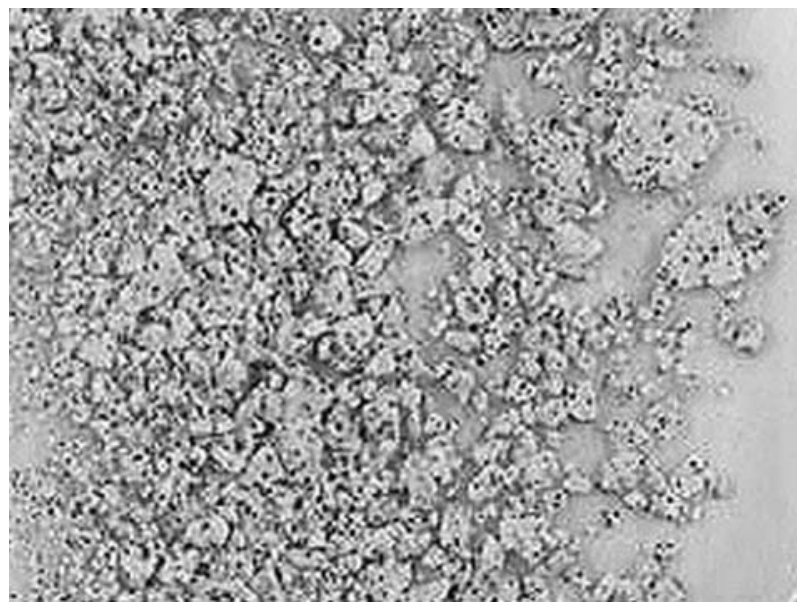

Figure 1. 'Pesta' granules showing microsclerotia beginning to germinate $8-10 \mathrm{~h}$ after exposure to water in a petri dish. Microsclerotia (dark particles) are observed on, or within, the 'Pesta' granules. 


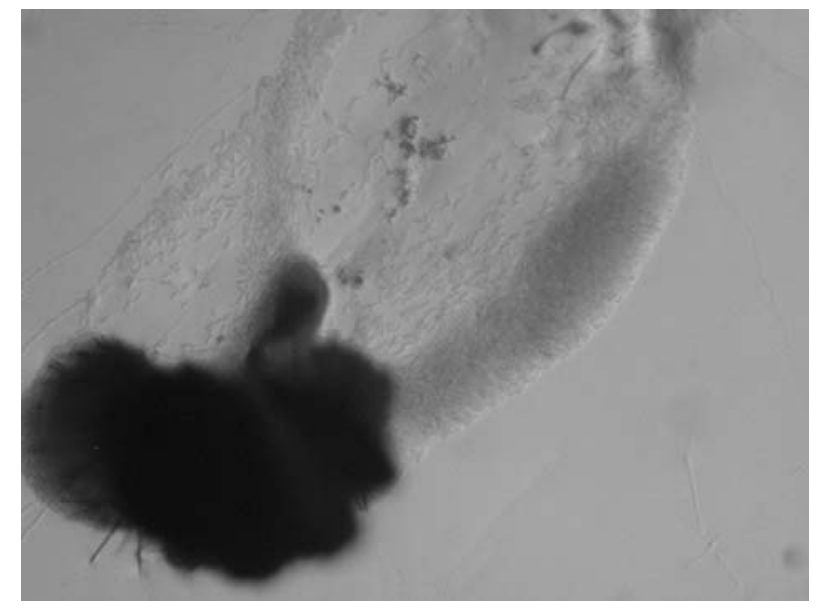

Figure 2. Microsclerotia (large dark structure) from a 'Pesta' granule, stored 10 years at $4{ }^{\circ} \mathrm{C}$, producing conidia (much smaller crescent-shaped structures) after incubation on water agar for $72 \mathrm{~h}$ at $25^{\circ} \mathrm{C}$.

\section{Greenhouse bioassay of granules}

With PE and PPI treatments, weed mortality of hemp sesbania seedlings was 94\% after 14 days (Figure 3). Emerging seedlings were killed as a result of infection of root and hypocotyl tissues, at or below the soil line, by fungal spores produced by microsclerotia in the granules. A similar value $(96 \%)$ was found for biomass reduction caused by the microsclerotia, indicating very rapid seedling death (data not shown). POE treatments were significantly less effective with only $76 \%$ weed mortality (Figure 3 ). In this case, the biomass reduction was $78 \%$, indicating that seedling death was not as rapid as in the PE and PPI treatments (data not shown). Fungus-free 'Pesta' granules had no effect on plant mortality or biomass reduction in any of the treatments.

\section{Field experiments}

Hemp sesbania was effectively controlled in plots treated PPI or PE receiving the higher rates (168 and $336 \mathrm{~kg} \mathrm{ha}^{-1}$ ) of inoculum during both years of these experiments (Figure 4). As in greenhouse tests, emerging hemp sesbania plants were infected by $C$. truncatum conidia produced from microsclerotia. Lesions formed near the soil line, eventually girdling and killing infected plants. Infected plants were collected and spores resembling $C$. truncatum were observed 


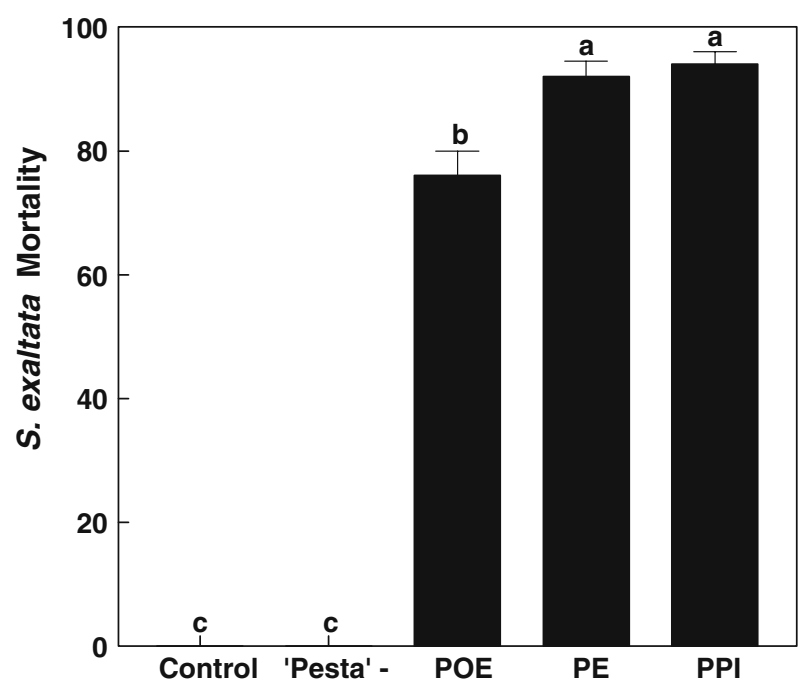

Figure 3. Biocontrol of Sesbania exaltata in the greenhouse with C. truncatum microsclerotia 'Pesta' granules, 14 days after treatment. Treatments were: pre-plant incorporated (PPI), pre-emergence (PE), and post-emergence (POE). Application rates were the equivalent of $c a .100 \mathrm{~kg} \mathrm{ha}^{-1}$. Error bars represent \pm 1 standard error of means of three replications of each treatment. Values of histogram bars with the same letters are not significantly different according to Fisher's Protected LSD test at $p=0.05$.

microscopically. The fungus isolated from infected tissues was confirmed to be C. truncatum using Koch's postulates (Tuite, 1969). Likewise in greenhouse experiments, POE applications were significantly less effective than PE or PPI during both years of field-testing (Figure 4). Using data from Figure 4, $t$-test $(p=0.05)$ analyses (Gomez and Gomez, 1984), showed no statistical differences in hemp sesbania control or soybean yield in plots treated PPI at $336 \mathrm{~kg} \mathrm{ha}^{-1}$ and plots treated with acifluorfen, an effective chemical herbicide against this weed in soybeans (Vencill, 2002). Furthermore, data trend lines and $R^{2}$ values (Figure 4) suggest that increased weed control might be achieved at inoculum rates above $336 \mathrm{~kg} \mathrm{ha}^{-1}$, but concomitant increased soybean yields would not likely occur. The rates of 'Pesta' granules required for acceptable weed control probably exceed rates acceptable for practical use and for commercial development of this bioherbicide. However, less than $0.5 \%$ of the total weight of the granules is due to the active ingredient (microsclerotia), with the remainder due to the flour and kaolin components, unspent media, and moisture. Thus, in field treatments receiving 'Pesta' granules at 168 and $336 \mathrm{~kg} \mathrm{ha}^{-1}$, the active ingredient rate would be $>0.84$ 

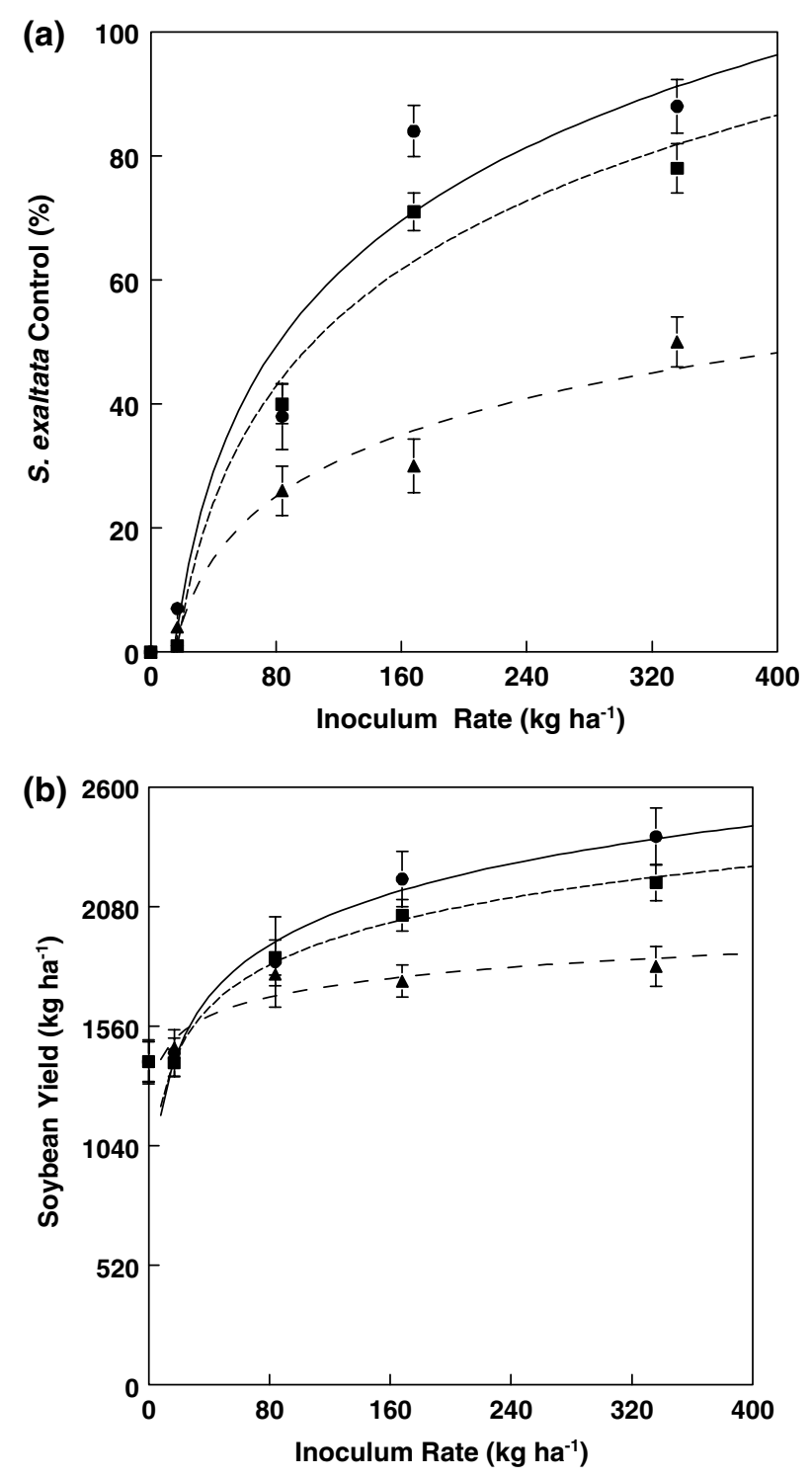

Figure 4. Biocontrol of $S$. exaltata (a) and soybean yield (b) in field test plots treated with $C$. truncatum microsclerotia formulated in 'Pesta' granules. Circles, squares, and triangles represent PPI, PE, and POE treatments, respectively. Error bars of symbol values are \pm 1 standard error of means of four replications for each inoculum rate. Regression curves for PPI, PE, and POE treatments are represented by solid lines, dashed lines, and dotted lines, respectively. Curve-fit coefficients for (a) were: PPI, $y=-7.57+29.18$ with $R^{2}=0.92 ;$ PE, $y=-75.99+27.13$ with $R^{2}=0.97$; POE, $-38.00+14.39$ with $R^{2}=0.95$ and for (b) were PPI, $y=502.01+321.94$ with $R^{2}=0.98$; PE, $y=657.18+266.75$ with $R^{2}=0.99$; POE, $y=1169.75+$ 117.94 with $R^{2}=0.85$. 


\section{S. EXALTATA BIOCONTROL WITH C.TRUNCATUM}

and $>1.68 \mathrm{~kg} \mathrm{ha}^{-1}$, respectively. Lighter inert fillers, more critical measurements of media, and use of drier granules could reduce the total weight of the formulated product. Another and possibly better approach to reduce the granule rates is the use of smaller granules. The granules used in these experiments were 14 to 18 -mesh ( $c a .1 .0$ $1.4 \mathrm{~mm}$ dia.). In field treatments receiving 168 and $336 \mathrm{~kg} \mathrm{ha}^{-1}$, this amounts to 0.35 and 0.70 granules $\mathrm{cm}^{-2}$, respectively. At these same rates with granules 18 to 30 -mesh $(0.60-1.0 \mathrm{~mm}$ dia.) these values are 0.94 and 1.87 granules $\mathrm{cm}^{-2}$, respectively. Previous work has shown that close proximity of mycoherbicidal granules with target weeds is critical for infection and weed kill (Boyette and Walker, 1985). The use of smaller granules could improve the weed control potential via better coverage of soil and/or plant surfaces.

Contrary to this idea, there is some evidence that producing 'Pesta' granules of smaller size reduces fungal viability, possibly as a result of susceptibility to heat convection, mechanical injury to fungal propagules, or both (Connick et al., 1991). Also one report indicated reduced viability of the bioherbicidal fungus Fusarium oxysporum formulated in similar small-sized 'Pesta' granules (Hebbar et al., 1998). One solution to these problems is the use of a formulation production system that is less damaging to the bioherbicidal organisms, such as that offered by extrusion technology. Research has shown that an extrusion system can produce smaller, more uniformly shaped granules that retain high fungal viability (Daigle et al., 1997).

The present study has demonstrated the successful use of soil applications of microsclerotia of the bioherbicide Colletotrichum truncatum formulated in 'Pesta' granules to effectively control hemp sesbania, one of the most widespread and troublesome weeds in the Mississippi Alluvial Plain (Dowler, 1997). Most bioherbicide research to date, has been directed towards the use of pathogens that promote disease above the soil surface (Templeton and Heiny, 1990; Charudattan, 1991; TeBeest, 1991; Rosskopf et al., 1999; Charudattan, 2001). However, significant progress has been made using soilborne pathogens as bioherbicides (Boyette et al., 1984; Weidemann and Templeton, 1988; Boyette et al., 1993a, Boyette and Abbas 1995; Abbas and Boyette, 2000; Charudattan, 2000). For soilborne bioherbicides, short-term fluctuations in environmental conditions, such as soil moisture and temperature, are less critical because the soil acts as a buffer to resist the rapid environmental changes often encountered above ground (Weidemann et al., 1995). The versatility of $C$. truncatum to control hemp sesbania with fungal spores in liquid carrier adjuvants, or as 


\section{DOUGLAS BOYETTE ET AL.}

granules containing spores, microsclerotia, or mycelial fragments should make this weed pathogen an attractive candidate for commercial bioherbicidal development.

\section{Acknowledgements}

The authors thank Jimmy R. McAlpine, Terry A. Newton, Albert J. Tidwell, and Angela R. Payne for valuable technical assistance.

\section{Note}

1. Mention of a trademark, proprietary product, or vendor does not constitute a guarantee or warranty of the product by USDA-ARS and does not imply its approval to the exclusion of other products or vendors that may also be suitable.

\section{References}

Abbas, H.K. and C.D. Boyette, 2000. Solid substrate formulation of the mycoherbicide Colletotrichum truncatum for hemp sesbania (Sesbania exaltata) control. Biocontrol Sci. Technol. 10: 297-304.

Agrios, G.N., 1988. Plant Pathology. 3rd ed. Academic Press, San Diego, CA. 803 pp.

Boyette, C.D., G.E. Templeton and L.R. Oliver, 1984. Texas gourd (Cucurbita texana) control with Fusarium solani f. cucurbitae. Weed Sci. 32: 649-655.

Boyette, C.D. and H.L. Walker, 1985. Evaluation of Fusarium lateritium as a biological herbicide for controlling velvetleaf (Abutilon theophrasti) and prickly sida (Sida spinosa). Weed Sci. 34: 106-109.

Boyette, C.D., H.K. Abbas and W.J. Connick Jr., 1993a. Evaluation of Fusarium oxysporum as a potential bioherbicide for sicklepod (Cassia obtusifolia), coffee senna (C. occidentalis), and hemp sesbania (Sesbania exaltata). Weed Sci. 41: 678-681.

Boyette, C.D., P.C. Quimby Jr., C.T. Bryson, G.H. Egley and F.E. Fulgham, 1993 b. Biological control of hemp sesbania (Sesbania exaltata) under field conditions with Colletotrichum truncatum formulated in an invert emulsion. Weed Sci. 41: 497-500.

Boyette, C.D. and H.K. Abbas, 1995. Weed control with mycoherbicides and phytotoxins: a non-traditional application of allelopathy. In: F.E. Einhellig and Inderjit (eds), Insights Into Allelopathy. Amer. Chem. Soc., Washington D.C. pp. 280-299.

Charudattan, R., 1991. The mycoherbicide approach with plant pathogens. In: D.O. TeBeest, (ed), Microbial Control of Weeds. Chapman and Hall, New York. pp. 24-57.

Charudattan, R., 2000. Current Status of Biological Control of Weeds. In: G.G. Kennedy and T.B. Sutton (eds), Emerging Technologies for Integrated Pest Management: Concepts, Research, and Implementation. American Phytopathological Society Press, St. Paul, MN. pp. 269-288.

Charudattan, R., 2001. Biological control of weeds by means of plant pathogens: significance for integrated weed management in modern agro-ecology. BioControl 46: $229-260$. 


\section{S. EXALTATA BIOCONTROL WITH C.TRUNCATUM}

Connick, W.J. Jr., C.D. Boyette and J.R. McAlpine, 1991. Formulation of mycoherbicides using a pasta-like process. Biol. Control 1: 281-287.

Connick, W.J. Jr., D.J. Daigle, C.D. Boyette, K.S. Williams, B.T. Vinyard and P.C. Quimby Jr., 1996. Water activity and other factors that affect the viability of Colletotrichum truncatum conidia in wheat flour-kaolin granules. Biocontrol Sci. Technol. 6: 277-284.

Connick, W.J. Jr., M.A. Jackson, K.S. Williams and C.D. Boyette, 1997. Stability of microsclerotial inoculum of Colletotrichum truncatum encapsulated in wheat flourkaolin granules. World J. Microbiol. Biotechnol. 13: 549-545.

Daigle, D.J., W.J. Connick Jr., C.D. Boyette, K.S. Williams and M. Watson, 1997. Twin-screw extrusion of Pesta-encapsulated biocontrol agents. World J. Microbiol. Biotechnol. 13: 671-676.

Dowler, C., 1997. Weed Survey-Southern States: broadleaf crops subsection. Proc. South. Weed Sci. Soc. 48: 90-325.

Gomez, K.A. and A.A. Gomez, 1984. Statistical Procedures for Agricultural Research. John Wiley and Sons, New York. 791 pp.

Hebbar, K.P., R.D. Lumsden, J.A. Lewis, S.M. Poch and B. Baily, 1998. Formulation of mycoherbicidal strains of Fusarium oxysporum. Weed Sci. 46: 501-507.

Jackson, M.A. and R.J. Bothast, 1990. Carbon concentration and carbon to nitrogen ratio influence submerged culture conidiation by the potential bioherbicide Colletotrichum truncatum NRRL 13757. Appl. Environ. Microbiol. 56: 3435-3438.

Jackson, M.A. and D.A. Schisler, 1994. Liquid culture production of microsclerotia of Colletotrichum truncatum for use as bioherbicidal propagates. Mycol. Res. 99: 879884.

Jackson, M.A., B. Shasha and D.A. Schisler, 1996. Formulation of Colletotrichum truncatum microsclerotia for improved biocontrol of the weed hemp sesbania (Sesbania exaltata). Biol. Control 7: 107-113.

King, C.A. and L.C. Purcell, 1997. Interference between hemp sesbania (Sesbania exaltata) and soybean (Glycine max) in response to irrigation and nitrogen. Weed Sci. 45: 91-97.

Lorenzi, H.J. and L.S. Jeffery, 1987. Weeds of the United States and their Control. Van Nostrand Reinhold, Mississippi. p. 180.

Lovelace, M.L. and L.R. Oliver, 2000. Effects of interference and tillage on hemp sesbania and pitted morningglory emergence and seed production. Proc. South. Weed Sci. Soc. 53: 202.

McWhorter, C.G. and J.M. Anderson, 1979. Hemp sesbania (Sesbania exaltata) competition in soybeans (Glycine max). Weed Sci. 27: 58-64.

Rosskopf, E.N., R. Charudattan and J.B. Kadir, 1999. Use of plant pathogens in weed control. In: T.W. Fisher, T.S. Bellows, L.E. Caltagirone, D.L. Dahlsten, C. Huffaker and G. Gordh (eds), Handbook of Biological Control. Academic Press, San Diego, CA. pp. 891-911.

Schisler, D.A. and M.A. Jackson, 1996. Germination of soil-incorporated microsclerotia of Colletotrichum truncatum and colonization of the weed Sesbania exaltata. Can. J. Microbiol. 42: 1032-1038.

TeBeest, D.O., 1991. Ecology and epidemiology of fungal plant pathogens studied as biological control agents of weeds. In: D.O. TeBeest, (ed), Microbial Control of Weeds. Chapman and Hall, New York. pp. 97-114. 


\section{DOUGLAS BOYETTE ET AL.}

Templeton, G.E. and D.K. Heiny, 1990. Mycoherbicides. In: R.R. Baker and P.E. Dunn (eds), New Directions in Biological Control: Alternatives for Suppressing Agricultural Pests and Diseases. Alan R. Liss, Inc., New York. pp. 268-289.

Tuite, J., 1969. Plant Pathological Methods - Fungi and Bacteria. Burgess Pub. Co., Minneapolis, MN.

Vencill, W.K. (ed) 2002. Herbicide Handbook. 8th edn. Weed Science Society of America. pp. 3-5.

Weidemann, G.J. and G.E. Templeton, 1988. Control of Texas gourd, Cucurbita texana, with Fusarium solani f. sp. cucurbitae. Weed Technol. 2: 271-274.

Weidemann G.J., C.D. Boyette and G.E. Templeton, 1995. Utilization criteria for mycoherbicides. In: F.R. Hall and J.W. Barry, (eds), Biorational Pest Control Agents: Formulation and Delivery. ACS Symposium Series, American Chemical Society, Washington, DC. pp. 238-251. 